\title{
Polyclonal antibodies to the putative coat protein of Citrus leprosis virus $C$ expressed in Escherichia coli: Production and use in immunodiagnosis
}

\author{
Renata F. Calegario ${ }^{1}$, Eliane C. Locali², Dagmar R. Stach-Machado ${ }^{3}$, Luís Antônio Peroni ${ }^{3}$, Raquel \\ Caserta $^{2,4}$, Renato B. Salaroli ${ }^{1}$, Juliana Freitas-Astúa ${ }^{2,5}$, Marcos A. Machado ${ }^{2}$ \& Elliot W. Kitajima ${ }^{1}$ \\ ${ }^{1}$ Departamento de Fitopatologia e Nematologia, Escola Superior de Agricultura Luiz de Queiroz, Universidade de São Paulo, \\ 13418-900, Piracicaba, SP, Brazil; ${ }^{2}$ Centro APTA Citros Sylvio Moreira, Cx. Postal 4, 13560-970, Cordeirópolis, SP, Brazil; \\ ${ }^{4}$ Departamento de Anatomia, Biologia Celular, Fisiologia e Biofísica, Universidade Estadual de Campinas, 13100-000, \\ Campinas, SP, Brazil; ${ }^{5}$ EMBRAPA Mandioca e Fruticultura, Cruz das Almas, BA, Brazil
}

Author for correspondence: Renata F. Calegario, e-mail: rfaier@hotmail.com

\begin{abstract}
This work reports the in vitro expression of Citrus leprosis virus C (CiLV-C) putative coat protein (p29) and the production of a polyclonal antibody to be used as a tool for serological diagnosis of citrus leprosis. The ORF2/RNA1, corresponding to $\mathrm{p} 29$, was cloned in pET28a and transformed into Escherichia coli cells (BL21). Expression of p29 was induced in vitro and the protein was purified and used for immunization of rabbits to produce the polyclonal antibody. The anti p29 serum was shown to be highly specific to CiLV-C detection by immunological methods (Western blot, PTA-ELISA, tissue blot and in situ immunolocalization), without cross reaction with healthy citrus plants or other cytoplasmic and nuclear viruses transmitted by Brevipalpus mites. These results demonstrate that the antibody against CiLV-C p29 protein is highly specific for CiLV-C detection. In situ immunogold labeling assays on thin sections of sweet orange leaf cells infected by CiLV-C demonstrated that short, bacilliform particles present within cisternae of the endoplasmic reticulum were specifically labeled, confirming their viral nature. The dense cytoplasmic viroplasm was also heavily labeled indicating that it represents a site of p 29 accumulation.
\end{abstract}

Key words: Citrus, diagnosis, electron microscopy, immunoassays, leprosis.

\section{INTRODUCTION}

Brazil is the largest producer of sweet orange [Citrus sinensis (L.) Osbeck] in the world, with exports of concentrated juice representing $80 \%$ of the world market (Boteon \& Neves, 2005). An adequate management supported by research has kept under control successive phytosanitary problems such as gummosis, tristeza, leprosis, decline, citrus variegated chlorosis, canker, sudden death, leaf miner, and, recently, huanglongbing (Mattos et al., 2005, Fundecitrus, 2011). Among these problems, citrus leprosis has been considered the main citrus viral pathogen in Brazil for the last several years (Müller et al., 2005; Bastianel et al., 2010). Its importance has significantly increased in other countries as well, since it is now present in most South and Central American countries, and has reached Mexico (Bastianel et al., 2010; Izquierdo-Castillo et al., 2011). The disease affects mainly sweet orange varieties and is characterized by the presence of local lesions on fruits, leaves and twigs, as well as premature leaf and fruit drop. It directly reduces production and lifespan of citrus plants. If left untreated, affected plants undergo severe dieback followed by their death (Rodrigues et al.,
2003; Bastianel et al., 2010). The causal agent of leprosis is Citrus leprosis virus $C$ (CiLV-C), which is transmitted by the false spider mite Brevipalpus phoenicis (Geijskes) (Acari:Tenuipalpidae). Every year, control of the mite vector costs Brazilian growers around US\$ 100 million on acaricides (Rodrigues et al., 2003).

In 2003, part of the genome of CiLV-C was sequenced generating the first molecular tool for its detection (Locali et al., 2003). Based on this work, the complete genome of CiLV-C was obtained and revealed to be composed by two ssRNA molecules of positive sense, with RNA1 of 8,745 nucleotides (nt) and RNA2 of 4,986 nt (Locali-Fabris et al., 2006; Pascon et al., 2006). Recently, CiLV-C was classified as the type member of a new genus of plant viruses, Cilevirus, due to the differences of its genome organization from other known viruses (Locali-Fabris et al., 2006; 2012).

Although molecular tools for CiLV-C detection are well established and efficient, antibodies against viral proteins are desirable because they lead to less costly diagnostic procedures and can be used for in situ detection of antigens. Because CiLV-C virions have been elusive to purify probably due to their labile nature, a strategy would be to express viral proteins in vitro and produce antibodies, 
either mono- or polyclonal, after their purification. An attempt to express the MP (ORF 3, RNA 2) of CiLV-C and produce antibody was successful, but possibly due to the distinct folding pattern of the expressed protein, this antibody reacted poorly with native MP and was not suitable for immunoassays (Calegario et al., 2012). Another approach was then attempted, expressing the $\mathrm{p} 29$ protein, a structural putative coat protein of the virion (ORF 2, RNA 1). This route was successful and this paper reports details of the in vitro expression of CiLV-C p29 protein, the production of a polyclonal antibody against it, and its use in immunoassays to detect CiLV-C in vitro or in situ.

\section{MATERIAL AND METHODS}

\section{Plant material}

Lesions on sweet orange leaves caused by CiLV-C, either from field plants or those experimentally infected with viruliferous mites, were used as inoculum source. These samples were collected in unsprayed experimental fields from Cordeirópolis, Piracicaba and Mogi-Mirim, state of São Paulo, Brazil, where leprosis was endemic. Those used in immunogold labeling assays came from Mexico, Paraguay, Venezuela and Argentina, as well as from different parts of Brazil (Table 1).

\section{Nucleic acid extraction and RT-PCR}

Total RNA was extracted from samples of CiLVC-infected 'Pera' sweet orange leaf lesions collected at Cordeirópolis, SP, and used for cDNA synthesis as described previously by Locali et al. (2003). The gene corresponding to p29, putative coat protein, was amplified by RT-PCR using specific primers with EcoRI and XhoI restriction sites. The reaction consisted of $3 \mu \mathrm{L}$ of cDNA, $2.5 \mu \mathrm{L}$ of $10 \mathrm{x}$ buffer, $0.9 \mu \mathrm{L}$ of $50 \mathrm{mM} \mathrm{MgCl}_{2}, 0.5 \mu \mathrm{L}$ of $2.5 \mathrm{mM}$ dNTP mix, 0.5 $\mu \mathrm{L}$ of each specific primer $(10 \mu \mathrm{M}), 0.2 \mu \mathrm{L}(1.5 \mathrm{U})$ of Taq DNA polymerase (Life Technologies) and sterile Milli-Q water to $25 \mu \mathrm{L}$ final volume. The reaction was performed using a PTC 100 (MJ Research) thermocycler programmed for 30 cycles composed by denaturation at $94^{\circ} \mathrm{C}$ for $30 \mathrm{~s}$, annealing at $56^{\circ} \mathrm{C}$ for $30 \mathrm{~s}$ and extension at $72^{\circ} \mathrm{C}$ for $40 \mathrm{~s}$. A final 5 minutes extension at $72^{\circ} \mathrm{C}$ was added to the last cycle. The PCR product was visualized in a $1 \%$ agarose gel containing $0.5 \mu \mathrm{g}$ ethidium bromide $\mathrm{mL}^{-1}$.

\section{CiLV-C p29 gene cloning and in vitro protein expression}

The $p 29$ CiLV-C gene was purified and subcloned into pGEM-T vector (Promega). After Escherichia coli DH5a transformation, the positive clones were selected, cleaved with EcoRI and XhoI and cloned into the pET-28a (Novagen) expression vector according to manufacturer's instructions. Recombinant plasmids were used to transform E. coli BL21 cells; positive clones were cultured in LB (Luria-Bertani) broth with kanamycin (50 $\mathrm{ng} / \mathrm{mL}$ ) and the protein expression was induced with 1 $\mathrm{mM}$ of IPTG (isopropyl $\beta$-D-1-thiogalactopyranoside) for $2 \mathrm{~h}$ under $300 \mathrm{rpm}$ agitation at $37^{\circ} \mathrm{C}$. The cells were centrifuged and the pellet was resuspended in $50 \mathrm{mM}$ tris$\mathrm{HCl}$ buffer, pH7.5, with $300 \mathrm{mM} \mathrm{NaCl}$. PMSF (protease inhibitor, phenyl 1 methyl 1 sulfonyl fluoride- $1 \mathrm{mM}$ ) and lysosyme $(1 \mathrm{mg} / \mathrm{mL})$ were added and incubated for $30 \mathrm{~min}$ at $4^{\circ} \mathrm{C}$. The cells were sonicated six times for $15 \mathrm{~s}$ at 45 potency

TABLE 1. Plant species, infected with CiLV-C, assayed by immunogold labeling using the antibody against CiLV-C p29 at 1:1000 dilution

\begin{tabular}{lll}
\hline \hline Sample & Origin of the sample & Resin' $^{1}$ \\
\hline 'Pera' Sweet orange & Centro APTA Citros, Cordeirópolis, SP, Brazil & Spurr/LR White \\
Sweet orange n.i. & Spurr/LR White \\
'Cravo' Mandarin & Distillery, ESALQ, Piracicaba, SP, Brazil & Spurr/LR White \\
'Valencia' Sweet ora nge & Distillery, ESALQ, Piracicaba, SP, Brazil & Spurr/LR White \\
Sweet orange n.i. & Tabasco, Mexico & Spurr \\
'Valencia' Sweet orange & Rio Branco, AC, Brazil & Spurr \\
'Valencia' Sweet orange & Maracay, Venezuela & Spurr \\
Sweet orange n.i. & Santa Cruz, Bolivia & Spurr \\
Sweet orange n.i. & Bahia, Brazil & Spurr \\
'Valencia' Sweet orange & Goiás, Brazil & Spurr \\
Phaseolus vulgaris L. cv. Mercana & Potrerillos, Panama & Spurr \\
& Amsterdam, The Netherlands (experimental & \\
P. vulgaris cv. Una & infection) & Spurr \\
Hibiscus rosa sinensis L. & Piracicaba, SP, Brazil (experimental infection) & Spurr \\
Swinglea glutinosa & Jaboticabal, SP, Brazil (experimental infection) & Spurr \\
Solanum violaefolium & Gamal, Colombia & Spurr
\end{tabular}

${ }^{1}$ Spurr (epoxy resin): samples fixed in aldehyde/osmium; LR White (acrylic resin): samples fixed only with aldehyde (paraformaldehyde + glutaraldehyde)

${ }^{2}$ Variety not identified. 
of a USC 1850A sonicator (Unique). After centrifugation at $13,000 \mathrm{rpm}$ for $25 \mathrm{~min}$ at $4^{\circ} \mathrm{C}$, the lysed supernatant was collected and the protein expression analyzed by SDSPAGE. The p29 protein was purified using IMAC column (Immobilized Metal Affinity Chromatography) with NiNTA resin and the adsorbed proteins were eluted from column with $200 \mathrm{mM}$ imidazole buffer $(50 \mathrm{mM}$ tris- $\mathrm{HCl}$, $300 \mathrm{mM} \mathrm{NaCl}, 200 \mathrm{mM}$ imidazole, pH 7.5). Each protein fraction collected was analyzed regarding its concentration and purity by SDS-PAGE.

\section{Antibody production}

The recombinant p29 protein $(150 \mu \mathrm{g})$ was homogenized in phosphate-buffered saline (PBS) (10 $\mathrm{mM}$ sodium phosphate buffer, $150 \mathrm{mM} \mathrm{NaCl}$, $\mathrm{pH}$ 7.2) and emulsified with Freund's complete adjuvant (Sigma Aldrich). The suspension was injected subcutaneously into a New Zealand rabbit. The subcutaneous injection was repeated twice, at weekly interval, with recombinant p29 protein at 200 and $300 \mu \mathrm{g}$ concentrations, respectively, emulsified with Freund's incomplete adjuvant. A booster intravenous injection of $400 \mu \mathrm{g}$ of the recombinant protein was given on day 42 and the rabbit was bled on day 50 , after the first injection.

\section{PTA-ELISA (Plate Trapped Antigen - Enzyme Linked Immunosorbent Assay)}

The PTA-ELISA was carried out as described by Mowat \& Dawson (1987). CiLV-C symptomatic leaf lesions from 'Pera' sweet oranges in different levels of disease development were tested. The samples were collected in a unsprayed experimental field from Centro APTA Citros Sylvio Mvoreira (CCSM), Cordeirópolis, São Paulo, Brazil, and visually separated into three categories: young lesions (YL)- small chlorotic spots, intermediary lesions (IL)- round, pale green spots, ca. $5 \mathrm{~mm}$ in diameter, and old lesions (OL), large, up to $10 \mathrm{~mm}$ in diameter, pale green usually with gummy rings (Figure 1). Extracts of these lesions, prepared in the presence of $0.01 \mathrm{M}$ phosphate buffer, $\mathrm{pH} 7.0(1 \mathrm{~g} / \mathrm{L} \mathrm{mL})$, were tested in duplicate in 1:50 dilution (w/v) with the serum against $\mathrm{p} 29$ diluted at 1:1000, 1:2000 and 1:5000. Tissues from healthy plants in the same conditions of dilution were used as negative controls. We also evaluated sweet oranges leaves infected by CiLV-C from fields located at Mogi Mirim and Piracicaba, state of São Paulo, and Frutal, state of Minas Gerais, Brazil. These samples were collected by researchers from FUNDECITRUS (Fundo de Defesa da Citricultura) and sent to our laboratory to be tested. One sample of dried leprosis infected leaf of 'Valencia' sweet orange, from Tabasco, Mexico, was also tested. In these cases there was no separation between young, intermediate and old lesions. The leaf extracts were tested at 1:50 dilution $(\mathrm{w} / \mathrm{v})$, as described above, with the serum against p29 diluted 1:5000. Negative-positive thresholds were set at two times the mean of healthy control sample absorbance. Additionally to sweet oranges, plants infected by other cytoplasmic type of Brevipalpus-transmitted viruses (BrTV-C) were also tested to verify the possibility of cross-reaction: Solanum violaefolium Schott./Solanum violaefolium ringspot virus (SvRSV), from Piracicaba, SP (Ferreira et al., 2007), Hibiscus rosa-sinensis L./Hibiscus green spot virus (HibGSV) from Piracicaba, SP (Kitajima et al., 2010), Ligustrum lucidum W.T. Aiton and Ligustrum sinensis Lour./Ligustrum ringspot virus (LigRSV) from Piracicaba, SP (Vergani, 1942; Kitajima et al., 2010), Passiflora edulis Sims. f. Alavicarpa Deg./Passion fruit green spot virus, from Piracicaba, SP (PFGSV) (Kitajima et al., 1997); Schefflera actinophyla (Endl.) Harms./Schefflera
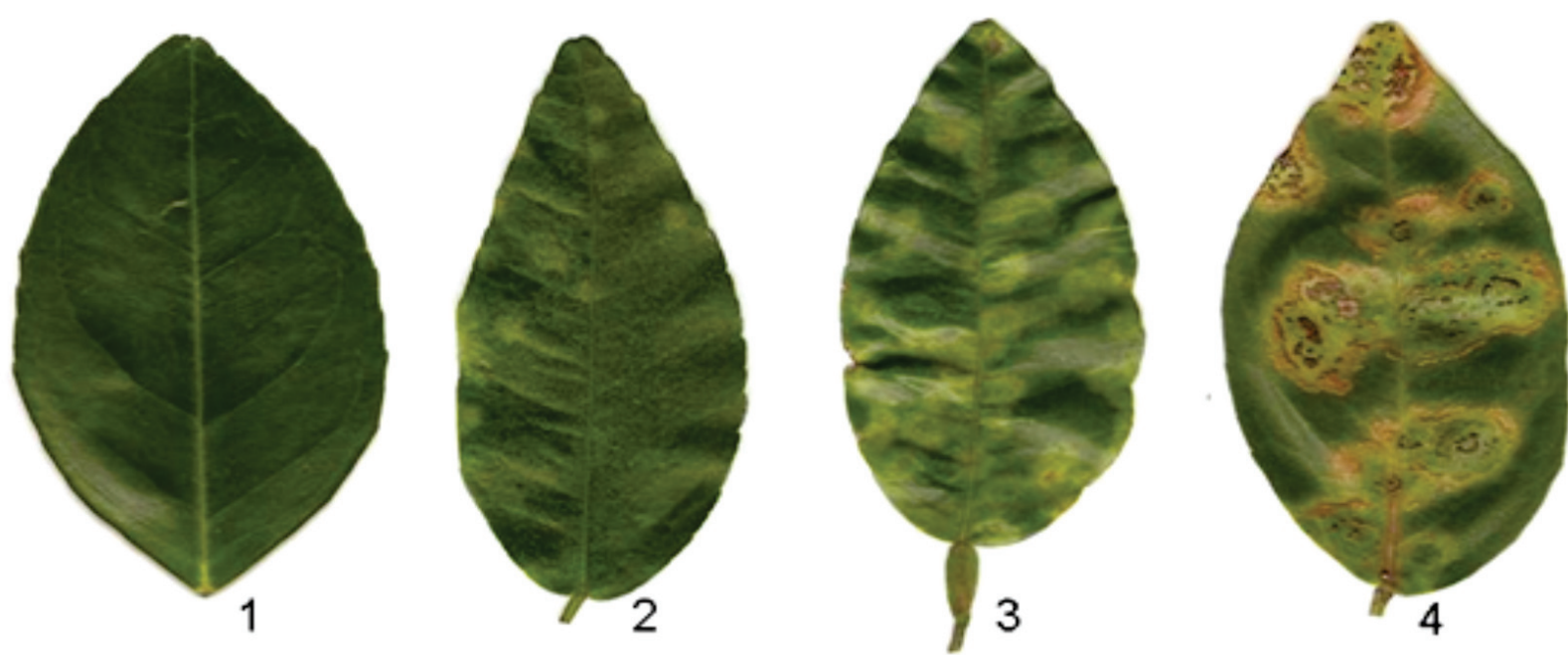

FIGURE 1. Leaves from 'Pera' sweet orange infected by CiLV-C at different levels of disease development collected at Cordeirópolis, SP, Brazil. 1. Healthy; 2. Young lesions; (YL); 3. Intermediary lesions (IL); 4. Old lesions (OL). 
Polyclonal antibodies to the putative coat protein of Citrus leprosis virus $C \ldots$

ringspot virus (SchefRSV), from Campinas, SP (Kitajima et al., 2010), Brunfelsia uniflora D. Don./Brunfelsia ringspot virus (BrRSV) from Piracicaba, SP (Kitajima et al., 2010), Arundina sp./BrTV-cytoplasmic type, from Manaus, AM (Kubo et al., 2009). The virus infection of these samples was previously confirmed by transmission electron microscopy (TEM) and the evaluated samples were leaf lesions stored at $-80^{\circ} \mathrm{C}$, without separation between young, intermediate and old lesions.

\section{Western Blot}

CiLV-C symptomatic leaf lesions from 'Pera' sweet oranges at different levels of disease development (YL, IL, OL), as above described, were tested by Western blot. However, in this case, they were ground in $0.5 \mathrm{M}$ tris buffer, $\mathrm{pH} 6.8$ at $1: 7$ ratio $(\mathrm{w} / \mathrm{v})$. The procedure was carried out as described by Calegario et al. (2012) using the CiLV-C p29 antibody diluted at 1:1000 (v/v).

\section{Tissue Blot}

The samples used in tissue blot consisted of CiLV-C infected leaves from sweet oranges (cvs. Pera and Bahia) and mandarin (Citrus reticulata Blanco cv. Cravo) from the CCSM, and the respective healthy, uninfected controls. One sample of sweet orange cv. Valencia infected by CiLV-C from Mexico was also tested. Leaves were decontaminated in $70 \%$ ethanol, rolled and cut with a sharp razor blade at the region of the local lesion. The sectioned leaf surface was gently pressured against a nitrocellulose membrane (EMD Millipore), which was dried by incubation at room temperature for 20 minutes. Imprinted membranes were processed as described by Garnsey et al. (1993) using the antibody against p29 at 1:1000 dilution. Attempts to detect CiLV-C in individual viruliferous mites, colonizing leprotic lesions on leaves or fruits of 'Pera' sweet orange, were also made. For this purpose, twenty mites were individually squashed on the surface of the membrane and then processed as above described.

\section{In situ immunolocalization}

CiLV-C leaf lesions were fixed in a modified Karnovsky solution [2\% (w/v) paraformaldehyde, 2.5\% (w/v) glutaraldehyde with $0.05 \mathrm{M}$ cacodylate buffer, $\mathrm{pH}$ 7.2] for 1-2 h, dehydrated in a graded ethanol series and embedded in LR White resin (Electron Microscopy Sciences) (Table 1). Blocks were sectioned in an EM U6 ultramicrotome (Leica Microsystem) equipped with a diamond knife (Diatome) and the sections mounted on 100 mesh nickel grids covered with Formvar (Electron Microscopy Sciences). Sections were pre-incubated in $1 \%(\mathrm{w} / \mathrm{v})$ of BSA (Sigma Aldrich) diluted in PBS plus $0.375 \%(\mathrm{w} / \mathrm{v})$ glycine (Sigma Aldrich) for $30 \mathrm{~min}$, and then incubated for $5 \mathrm{~h}$ in the p29 antibody at 1:1000 diluted in PBS plus $0.1 \%(\mathrm{w} / \mathrm{v})$ of BSA. After washing with PBS, sections were treated with protein A (Sigma Aldrich) conjugated to colloidal gold of $15 \mathrm{~nm}$ (Sigma Aldrich), diluted 1:50 in PBS with $2 \%(\mathrm{w} / \mathrm{v})$ of fish skin gelatin (Sigma Aldrich) and polyethylene glycol 20,000 (1.5 mL $1 \%$ to $100 \mathrm{~mL}$ solution) for $1 \mathrm{~h}$ (Maunsbach \& Afzelius, 1999; Vandenbosch, 1990). Gold particles were silver enhanced to increase the size with the R-Gent SE-EM kit (Aurion), following instructions of the manufacturer. Sections were stained with $3 \%$ aqueous uranyl acetate and Reynolds lead citrate (10 min each) and examined in an EM 900 transmission electron microscope (Carl Zeiss). As negative controls we used healthy, uninfected 'Pera' sweet orange tissue from Centro Apta Citros Sylvio Moreira, Cordeirópolis, SP, and 'Valencia' sweet orange infected by a different virus, Citrus leprosis virus, nuclear type (CiLV-N) (Rodrigues et al., 2003) from Monte Alegre, SP. Attempts to immunogold-label presumed viral particles and viroplasma were also made on sections embedded in epoxy Spurr medium (Electron Microscopy Sciences) and formaldehyde/osmium fixed from different origins (Table 1), but after treating the sections with $0.56 \mathrm{mM}$ aqueous sodium periodate (Merck) for 15 minutes, to expose antigenic sites (Vandenbosch, 1990). In these assays, CiLV-C infected leaf samples included not only sweet oranges from different localities, but also from other plant species, naturally (Swinglea glutinosa) or experimentally infected with CiLV-C (H. rosa sinensis, P. vulgaris, S. violaefolium). Additionally, leaf lesions from plants infected by other cytoplasmic type of BrTVs and formaldehyde fixed/LRWhite embedded were also tested with the CiLV-C p29 antibody, as described in the PTA-ELISA topic of this Material and Methods.

\section{RESULTS}

\section{Cloning and expression of p29 gene}

The p29 protein was successfully cloned in the pET28a vector and the best period for induction of expression was determined as being $2 \mathrm{~h}$ at $37^{\circ} \mathrm{C}$ by SDSPAGE. The expressed protein had a molecular mass of 29 $\mathrm{kDa}$, just as estimated by Locali-Fabris et al. (2006) for the CiLV-C putative coat protein. The expression of the protein was $0.277 \mathrm{~g} / \mathrm{L}$ (or soluble protein per liter of bacterial broth) of concentration post purification, and was present in $4 \mathrm{~mL}$ of $200 \mathrm{mM}$ imidazole effluent solution.

\section{Immunological assays}

\section{PTA-ELISA}

The three types of CiLV-C leaf lesions (YL, IL and $\mathrm{OL})$ presented positive reactions in all tested dilutions of p29 antibody (Table 2). Despite the fact that old lesions presented less intense reactions than the younger ones, it did not compromise the efficiency of the serological test, once the absorbance values of these samples were from 6 to 12 times higher than those of the negative controls. In this study, the optimal antibody dilution was determined by the highest value obtained from the correlation between 
TABLE 2. PTA-ELISA using different dilutions of CiLV-C p29 antibody. Optical density measured $3 \mathrm{~h}$ after adding the substrate. Pera sweet orange leaf lesions from Centro APTA Citros Sylvio Moreira, Cordeirópolis, SP, Brazil

\begin{tabular}{|c|c|c|c|c|}
\hline \multirow[t]{2}{*}{ Sample } & \multicolumn{4}{|c|}{ Leaf extract (Absorbance at $405 \mathrm{~nm}$ ) } \\
\hline & Test 1 & Test 2 & Average $^{1,2}$ & $\mathrm{~S} / \mathrm{H}$ ratio $^{1}$ \\
\hline & \multicolumn{4}{|c|}{ Antibody against p29 diluted at 1:1000 } \\
\hline Healthy & 0.223 & 0.206 & 0.214 & \\
\hline $\mathrm{YL}^{2}$ & 1.884 & 1.781 & 1.833 & 8.57 \\
\hline IL & 1.816 & 1.834 & 1.825 & 8.52 \\
\hline \multirow[t]{2}{*}{$\mathrm{OL}$} & 1.404 & 1.510 & 1.457 & 6.81 \\
\hline & \multicolumn{4}{|c|}{ Antibody against p29 diluted at 1:2000 } \\
\hline Healthy & 0.122 & 0.161 & 0.141 & \\
\hline YL & 1.634 & 1.529 & 1.582 & 11.22 \\
\hline IL & 1.548 & 1.515 & 1.532 & 10.86 \\
\hline \multirow[t]{2}{*}{$\mathrm{OL}$} & 1.145 & 1.239 & 1.192 & 8.45 \\
\hline & \multicolumn{4}{|c|}{ Antibody against p29 diluted at 1:5000 } \\
\hline Healthy & 0.069 & 0.061 & 0.065 & \\
\hline YL & 1.097 & 1.058 & 1.078 & 16.59 \\
\hline IL & 0.891 & 0.814 & 0.853 & 13.12 \\
\hline $\mathrm{OL}$ & 0.760 & 0.818 & 0.789 & 12.14 \\
\hline
\end{tabular}

${ }^{1}$ Sample/healthy

${ }^{2} \mathrm{YL}$, young lesions, IL, intermediate lesions and OL, old lesions

the absorbance of infected and healthy plants. Thus, the antiserum best performance was at 1:5000, where infected plants showed absorbance from 12 to 16 times higher than the negative controls, after 3 hours incubation with the substrate. On 1:2000 and 1:1000 dilutions, the absorbance was from 8 to 11 and 6 to 8 times higher than the negative controls, respectively. No reaction was seen in the extracts from control, healthy sweet oranges leaves. In addition, sweet oranges leaves brought from fields located in Mogi-Mirim and Piracicaba, SP, and in Frutal, MG, were also tested with CiLV-C p29 antibody presenting positive reaction by ELISA (Table 3). In these cases negative-positive thresholds were set at two times the mean of healthy control sample absorbance. Furthermore, a sample from sweet orange leaf showing typical leprosis symptoms from the state of Tabasco, Mexico, also reacted positively in ELISA (Table 4). All the plant species infected with other BrTVs did not present positive reaction by PTA-ELISA (data not shown), confirming that no cross reaction is observed between the produced antiserum and these tested BrTVs.

\section{Western Blot}

In Western blot, the antiserum developed against the expressed p29 of CiLV-C showed a positive reaction with the purified $29 \mathrm{KDa}$ protein, and also with the p29 protein present in the three different types of local lesions evaluated (Figure 2). Even though IL and OL extracts gave consistently a stronger signal than YL in Western blot assays repeated several times, our results suggest that this is a good method for CiLV-C detection in planta for all of the tested conditions.

\section{Tissue blot}

The outline of the leaves infected by CiLV-C imprinted on the nitrocellulose membrane by tissue blot was clearly visible. Leaves of tested sweet orange varieties

TABLE 3. PTA-ELISA from symptomatic sweet orange and mandarin leaves collected in CiLV-C infected fields. CiLV-C p29 antibody diluted at 1:5000. Optical density measured $2 \mathrm{~h}$ after adding the substrate

\begin{tabular}{|c|c|c|c|c|c|c|}
\hline \multirow[t]{2}{*}{ Sample $^{1}$} & \multirow[t]{2}{*}{ Origin } & \multicolumn{5}{|c|}{ Leaf extract (Absorbance at 405nm) } \\
\hline & & Test 1 & Test 2 & Test 3 & Average 1- 3 & $2 x$ average \\
\hline $\begin{array}{l}\text { Healthy 'Pera' } \\
\text { Sweet orange }\end{array}$ & $\begin{array}{l}\text { Centro APTA Citros, } \\
\text { Cordeirópolis, SP, Brazil }\end{array}$ & 0.028 & 0.022 & 0.027 & 0.025 & 0.050 \\
\hline 'Pera' Sweet orange & $\begin{array}{l}\text { Centro APTA Citros, } \\
\text { Cordeirópolis, SP, Brazil }\end{array}$ & 0.422 & 0.398 & 0.399 & 0.406 & \\
\hline Sweet orange n.i. ${ }^{2}$ & Field 1, Piracicaba, SP, Brazil & 0.364 & 0.348 & 0.305 & 0.339 & \\
\hline Sweet orange n.i. & Field 2, Piracicaba, SP, Brazil & 0.090 & 0.091 & 0.076 & 0.085 & \\
\hline Sweet orange n.i. & $\begin{array}{l}\text { Field 1, Mogi-Mirim, SP, } \\
\text { Brazil }\end{array}$ & 0.232 & 0.251 & 0.231 & 0.238 & \\
\hline Sweet orange n.i. & $\begin{array}{l}\text { Field 2, Mogi-Mirim, SP, } \\
\text { Brazil }\end{array}$ & 0.147 & 0.129 & 0.124 & 0.133 & \\
\hline Sweet orange n.i. & $\begin{array}{l}\text { Field 3, Mogi-Mirim, SP, } \\
\text { Brazil }\end{array}$ & 0.106 & 0.096 & 0.076 & 0.092 & \\
\hline Sweet orange n.i. & Frutal, MG, Brazil & 0.092 & 0.057 & 0.072 & 0.073 & \\
\hline $\begin{array}{l}\text { Healthy 'Cravo' } \\
\text { Mandarin }\end{array}$ & Piracicaba, SP, Brazil & 0.016 & 0.002 & & 0.009 & 0.018 \\
\hline 'Cravo'Mandarin & Piracicaba, SP, Brazil & 0.089 & 0.082 & & 0.086 & \\
\hline
\end{tabular}

\footnotetext{
${ }^{1}$ In this test there was no separation between young, intermediate and old lesions
}

${ }^{2}$ Variety not identified. 
Polyclonal antibodies to the putative coat protein of Citrus leprosis virus $C \ldots$

TABLE 4. PTA-ELISA from sweet orange leaves collected in Brazil and Mexico. CiLV-C p29 antibody diluted at 1:5000. Optical density measured $2 \mathrm{~h} 30 \mathrm{~min}$ after adding the substrate

\begin{tabular}{|c|c|c|c|c|c|c|}
\hline \multirow[t]{2}{*}{ Sample $^{1}$} & \multirow[t]{2}{*}{ Origin } & \multicolumn{5}{|c|}{ Leaf extract (Absorbance at 405nm) } \\
\hline & & Test 1 & Test 2 & Test 3 & Average 1-3 & $2 x$ average \\
\hline $\begin{array}{l}\text { Healthy Sweet } \\
\text { orange n.i. }\end{array}$ & Piracicaba, SP, Brazil & 0.003 & 0.006 & 0.016 & 0.008 & 0.016 \\
\hline Sweet orange n.i. & Piracicaba, SP, Brazil & 0.073 & 0.065 & 0.065 & 0.068 & \\
\hline Sweet orange n.i & Tabasco, Mexico & 0.056 & 0.038 & 0.057 & 0.050 & \\
\hline Sweet orange n.i & Tabasco, Mexico & 0.107 & 0.078 & 0.072 & 0.086 & \\
\hline
\end{tabular}

${ }^{1}$ In this test there was no separation between young, intermediate and old lesions

${ }^{2}$ Variety not identified.

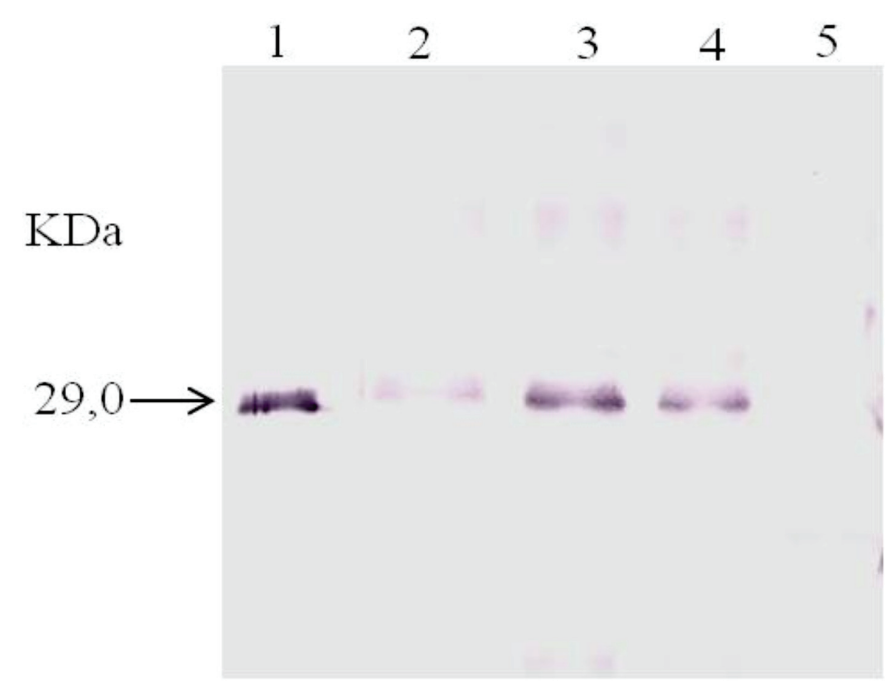

FIGURE 2. Western blot using the CiLV-C p29 antibody at 1:1000 dilution for the detection of: $\mathbf{1}$. Pure in vitro expressed p29 protein; 2. Young lesion; 3. Intermediate lesion; 4. Old lesion; 5. Healthy 'Pera' sweet orange - negative control (Cordeirópolis, SP, Brazil).
'Bahia', 'Valencia' and 'Pera' clearly showed positive reactions in the areas corresponding to the local lesions (Figure 3). No reaction was observed on imprints of healthy, control leaves.

\section{Immunogold labeling}

In all sections of leaf lesions caused by CiLV-C fixed in formaldehyde and embedded in LR White, a consistent labeling of the bacilliform particles and the viroplasm were observed (Figures $4 \mathrm{C}$, D). Labeling of the viroplasm was very intense (Figures $4 \mathrm{D}$ ), while less marked labeling was noticed on the bacilliform particles (Figure $4 \mathrm{C}$ ). Background was low, revealing the good specificity of the antibody. No labeling was visualized on healthy, uninfected samples, or on samples infected by CiLV-N and on sections of leaf lesions caused by other BrTVs tested (data not shown). In formaldehyde/osmium fixed and Spurr embedded tissues of CiLV-C infected materials from different origins, a faint, but consistent labeling was noticed on the viroplasm. These samples comprised sweet orange leaves infected with CiLV-C from different origins (Table 1) (Figure 4 E, F) and other plant species naturally or experimentally infected with this virus (data not shown).

\section{DISCUSSION}

This study reports the development of the first specific serological tool to detect CiLV-C. The putative coat protein, p29, was successfully expressed in vitro and a highly specific polyclonal antibody was raised in a rabbit. This anti p29 serum is able to recognize the putative capsid protein of CiLV-C present in infected citrus plants and other assay plants experimentally mite-infected with CiLV-C using PTA-ELISA and Western blot assays. CiLV-C could be detected both in young, small chlorotic lesions (YL) as well as in older, larger and somewhat necrotic lesions (OL) indicating that p29 is still present in the latter. Besides CiLV-C- infected samples from Brazil, PTAELISA was able to detect this virus in dried leaf samples from Mexico. The quantitative data produced by PTA-ELISA assay indicated that, under similar conditions, lesions from mandarin yielded less intense reaction than those from sweet orange, but the detection was efficient in both citrus species. The lesser amount of viral antigen in mandarin may be related 


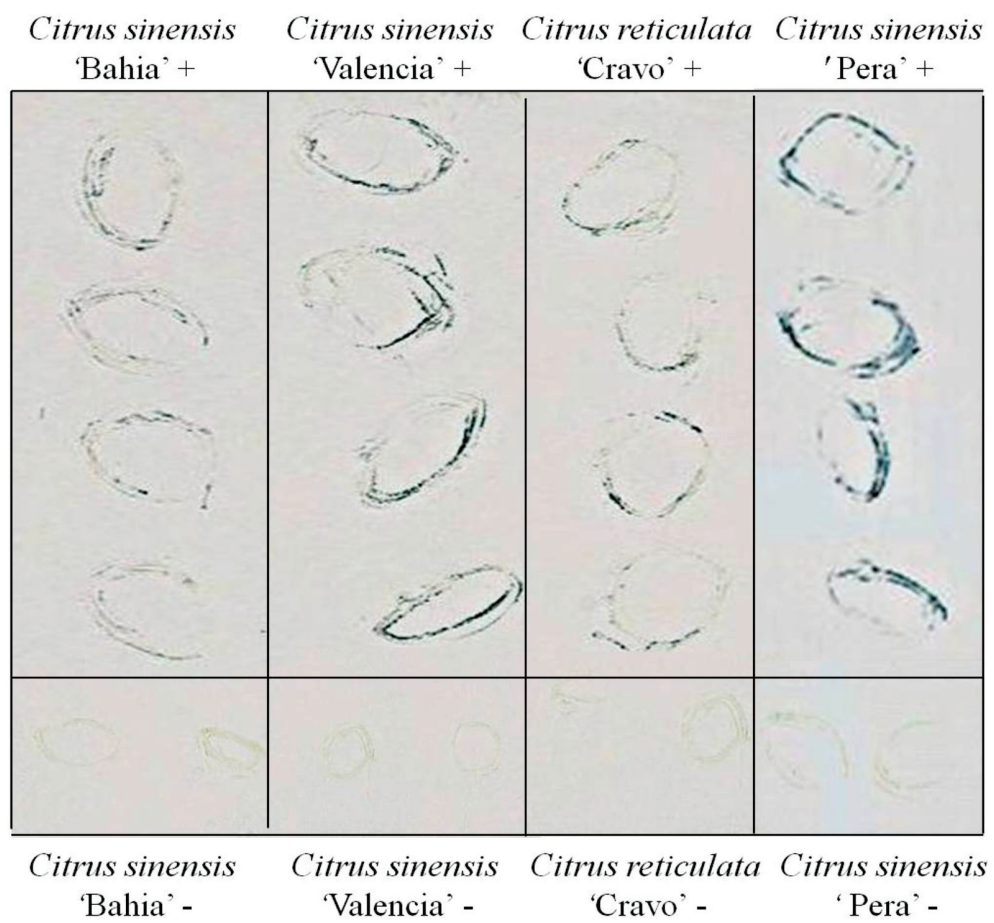

FIGURE 3. Example of a tissue blot experiment using leaf lesion imprints on nitrocellulose membrane labeled with CiLV-C p29 antibody at 1:1000 dilution. On the top of the figure the positive signs $(+)$ indicate the samples infected by CiLV-C. The negative controls (healthy) are indicated below with negative signs (-). Origin of the samples: Citrus sinensis 'Bahia' and 'Pera', SP, Brazil; Citrus sinensis 'Valencia', Tabasco, Mexico; Citrus reticulata 'Cravo', SP, Brazil. to it being less susceptible to the CiLV-C infection. This antibody is highly specific for CiLV-C, since in PTA-ELISA it did not react with extracts from either control uninfected tissues or other Brevipalpus-transmitted viruses. Thus, PTA-ELISA is, together with RT-PCR (Locali et al., 2003), an efficient and powerful tool to detect CiLV-C. It can be more cost effective than RT-PCR for the screening of large amount of samples with results in a shorter time.

Another application, a consequence from the availability of the specific antibody against p29, was the tissue blotting. Assays made with tissues from leprotic lesions gave consistent positive results while healthy controls were negative. This is a very simple and economic procedure, and allows testing samples from distant places, without the need of bringing them to the laboratory. Nitrocellulose membranes may be shipped to the local technicians, who can press the tissue with the lesion onto the membrane and then mail them back to the laboratory, where the blot can be processed and evaluated. Also, under favorable conditions it is possible to observe the distribution of the antigen in the tissue (Garnsey et al., 1993). Attempts to detect CiLV-C in individual mites that were feeding on sweet orange leaf lesions were unsuccessful, probably because the virus titer is extremely low. Even RT-PCR, which is a more sensitive test, requires at least 5-10 mites for consistent positive result (Kubo et al., 2011).

Transmission electron microscopy has shown that a characteristic feature of tissues from leprotic lesions is the presence of short, bacilliform particles within cisternae of the endoplasmic reticulum and a large, electron dense viroplasm in the cytoplasm (Figure. 4, A, B) (Colariccio et al., 1995; Kitajima et al., 2003; Rodrigues et al., 2003). The bacilliform particles were considered putative viral particles, while the viroplasm, a possible site of viral material accumulation and/or replication. The availability of the antibody opened the possibility to confirm these hypotheses. Immunogold labeling assays demonstrated the specific nature of the antibody against p29 with very low background and specific labeling on the bacilliform particles and viroplasm. The level of the labeling on the particles was less intense and this is due to the small amount of the antigen exposed by the sections. This labeling unequivocally confirms that these bacilliform particles represent CiLV-C virions. The viroplasm, on the other hand, was intensely labeled, indicating that there is a large accumulation of the $\mathrm{p} 29$ protein. It may represent the deposit of the excess of $\mathrm{p} 29$ protein expressed by the transcription/ translation of this gene, a situation reminiscent of the dense masses of tospovirus nucleocapsidal proteins (Kitajima et al., 1992). These results were obtained in samples fixed only by aldehyde and embedded in LRWhite resin, which is more suitable for immunogold labeling studies preserving the properties of the antigens. However, it has been shown that some degree of labeling is possible in tissues post-fixed in osmium and embedded in epoxy resins normally used only for ultrastructural studies, after oxidation to unblock the antigens (Vanderbosch, 1990). Assays were made on tissues of leaf lesions caused by CiLV-C on sweet orange from different parts of Brazil and from abroad (Mexico, Venezuela and Bolivia), as well as of some other plant 

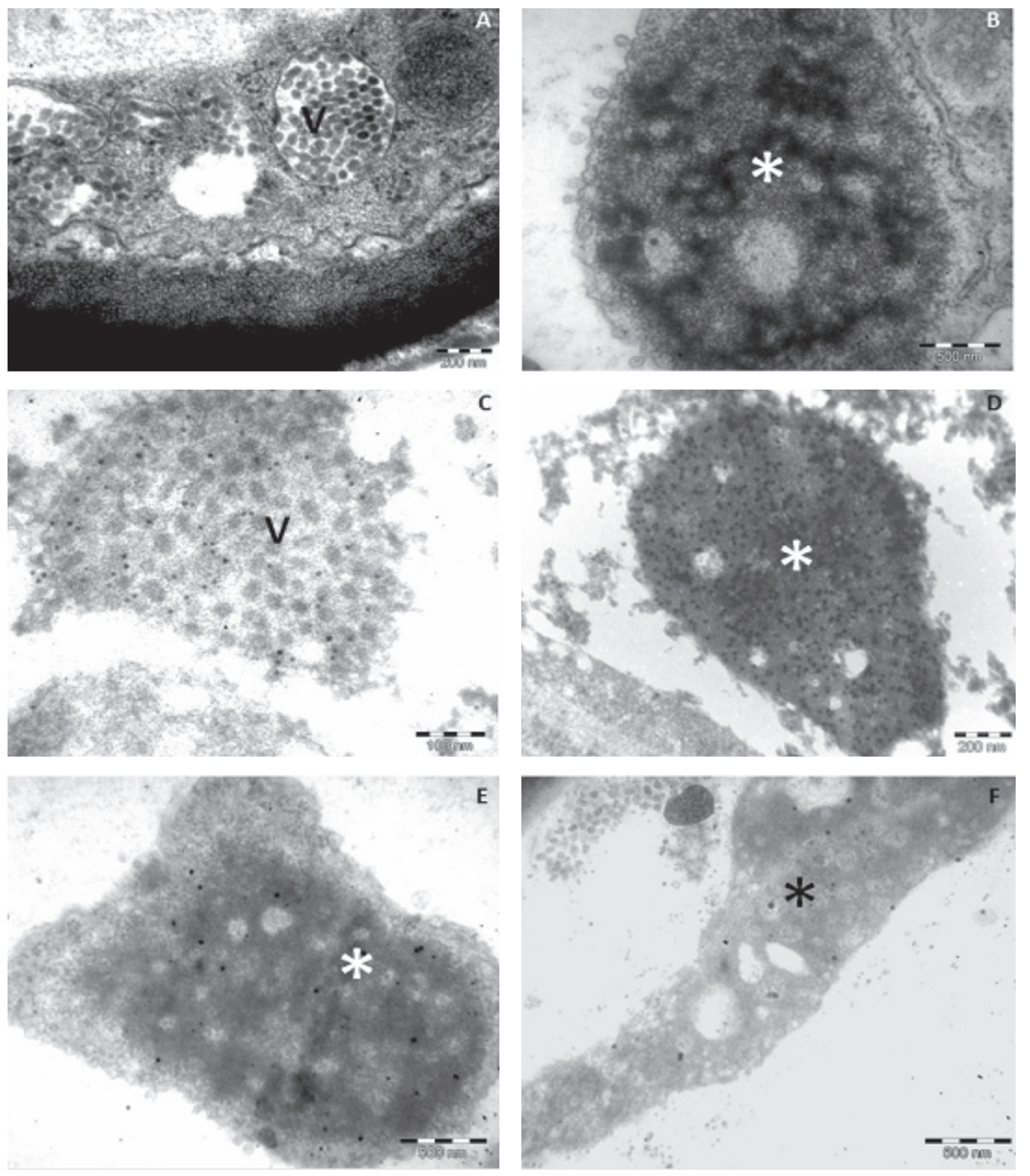

FIGURE 4. A.B. Transmission electron micrograph (TEM) of sections of aldehyde/osmium fixed Spurr embedded 'Pera' sweet orange leaf lesions caused by the infection of CiLV-C. A. Groups of short, bacilliform particles, presumed virions (v) are contained in cisternae of the endoplasmic reticulum; $\mathbf{B}$. An electron dense, vacuolated viroplasm (*) in the cytoplasm. Note groups of small vesicles attached to the tonoplast within the vacuole, next to the viroplasm; C.D. TEM of results of the in situ immunolabeling assays using anti-p29 polyclonal antibody in aldehyde-fixed and LRWhite embedded leaf lesion tissues of CiLV-C infected sweet orange; C. A pocket of the endoplasmic reticulum holding a large number of lightly labed virions (v); D. Cytoplasmic viroplasm (*) is intensely gold labeled. Gold particles were silver enhanced. E.F. Two examples of immunolabeling with anti-p29 serum on the viroplasm (*) in aldehyde/osmium-fixed leaf lesion tissues, after treatment with sodium periodate to exposed antigens. Labeling on viroplasm $\left({ }^{*}\right)$ is fainter than those observed in D, but consistent. Leaf lesions from sweet orange from: E. Rio Branco, AC, Brazil; F. Santa Cruz de la Sierra, Bolivia. 
species either naturally or experimentally infected by CiLV-C. A faint labeling could be observed on the viroplasm but not on bacilliform particles, showing that antigens could be detected to some degree under these conditions. Nevertheless the reaction, though faint, demonstrated that these tissues were infected by CiLV-C isolates, and the results are coherent with RTPCR data (Bastianel et al., 2010). The p29 accumulating in the viroplasm might be involved in the morphogenesis of the CiLV-C virions. Though not yet observed in CiLV-C infected materials, possible budding process in the membranes of the endoplasmic reticulum next to viroplasm has been noticed with some Brevipalpustransmitted viruses of the cytoplasmic type (Kitajima et al., 2003). Thus the morphogenesis process seems to be more akin to what happens with rhabdoviruses (Francki et al., 1985; Redinbaugh \& Hogenhout, 2005) than with tospoviruses (Kikkert et al., 1999), which involves the Golgi body. The excess of p29 expression might also be linked to other functions for this protein.

The CPs of many plant viruses are multifunctional and required throughout infection, in addition to being required for particle assembly (Herranz et al., 2012). For example, the $\mathrm{CP}$ of some viruses is directly or indirectly involved in the accumulation of viral plus-strand RNA (Yi et al., 2009; Herranz et al., 2012). Many CPs are also required for the virus infection to spread from cell-to-cell (Lee et al., 2011; Herranz et al., 2012; Schoelz et a., 2011) and/or for systemic spread throughout the plant (Kobori et al., 2002; Lee et al., 2011; Herranz et al., 2012). In addition, the coat proteins may be involved in vector transmission (Liu et al., 2002; Uzest et al., 2007), determination of the symptom (Lan et al., 2010), among others.

The present results successfully demonstrated the in vitro expression of CiLV-C p29 protein using a recombinant gene system, and an antiserum that can be efficiently used for immunodiagnosis in PTA-ELISA, Western blot, tissue blot and immunogold labeling. This antiserum is highly sensitive and specific to detect CiLV-C in infected tissue and does not cross-react with normal cell components or other Brevipalpus-transmitted viruses of the same group.

\section{ACKNOWLEDGMENTS}

This work is part of the research to fulfill the requirements for the Doctoral degree of the first author, who received a doctoral fellowship from FAPESP (2004/11799-0). The authors express gratitude to Fundecitrus for kindly providing CiLV-C infected plant materials from Mogi-Mirim, SP, and Frutal, MG, Brazil. Dried leprosisinfected sweet orange sample was kindly provided by I. Izquierdo-Castillo. This research received financial support from FAPESP (2008/52691-9), CNPq (47.1705/2009-8), and Embrapa.

\section{REFERENCES}

Bastianel M, Novelli VM, Kitajima EW, Kubo KS, Bassanezi RB, Machado MA, Freitas-Astúa J (2010) Citrus leprosis: Centennial of an unusual mite-virus pathosystem. Plant Disease 94:284-292.

Boteon M, Neves EM (2005) Citricultura brasileira: aspectos econômicos. In: Mattos Junior D, De Negri JD, Pio RM, Pompeu Junior J (Org.) Citros. Campinas SP. Instituto Agronômico/ FUNDAG. pp.19-36.

Calegario RF, Labate MVT, Peroni LA, Stach-Machado DR, Andrade MO, Freitas-Astúa J, Labate CA, Machado MA, Kitajima EW (2012) In vitro expression and antiserum production against the movement protein of the Citrus leprosis virus $C$ (CiLV-C). Tropical Plant Pathology 37:135-140.

Colariccio A, Lovisolo O, Chagas CM, Galletti SR, Rossetti V, Kitajima EW (1995) Mechanical transmission and ultrastructural aspects of citrus leprosis disease. Fitopatologia Brasileira 20:208213.

Ferreira PTO, Locali-Fabris EC, Freitas-Astua J, Antonioli-Luizon R, Gomes RT, Machado MA, Kitajima EW (2007) Caracterização de um vírus baciliforme isolado de Solanum violaefolium transmitido pelos ácaros Brevipalpus obovatus (Acari: Tenuipalpidae). Summa Phytopathologica 33:264-269.

Francki RIB, Milne RG, Hatta T (1985) Atlas of plant viruses. Boca Raton FL, USA. CRC Press.

Fundecitrus. Levantamento amostral - Greening 2011. Available at: http://www.fundecitrus.com.br/Pagina/cancrocitrico,315. Accessed on August 28, 2012.

Garnsey SM, Permar TA, Cambra M, Henderson CT (1993) Direct tissue blot immunoassay (DTBIA) for detection of Citrus tristeza virus (CTV). In: 12th Conference of IOCV, Proceedings... Riverside CA, USA. IOCV. pp. 39-50.

Herranz MC, Pallas V, Aparicio F (2012) Multifunctional roles for the N-terminal basic motif of Alfalfa mosaic virus coat protein: nucleolar/cytoplasmic shuttling, modulation of RNAbinding activity, and virion formation. Molecular Plant-Microbe Interactions 25:1093-1103.

Izquierdo-Castillo I, Diaz LFZ, Mendez W, Otero-Colina G, Freitas-Astúa J, Locali-Fabris EC, Moraes GJ, Calegario RF, Tassi AD, Kitajima EW (2011) Confirmation of the presence of the Citrus leprosis virus C (CiLV-C) in Southern Mexico. Tropical Plant Pathology 36:400-403.

Kikkert M, van Lent J, Storms M, Bodegom P, Kormelink $\mathrm{R}$, Goldbach R (1999) Tomato spotted wilt virus particle morphogenesis in plant cells. Journal of Virology 73:2288-2297.

Kitajima EW, Chagas CM, Rodrigues JCV (2003) Brevipalpustransmitted plant virus and virus-like diseases: cytopathology and some recent cases. Experimental and Applied Acarology 30:135160 .

Kitajima EW, Ávila AC, Resende RO, Goldbach RW, Peters D (1992) Comparative cytological and immunogold labeling studies of different isolates of tomato spotted wilt virus. Journal of Submicroscopic Cytology and Pathology 24:1-14.

Kitajima EW, Rezende JAM, Rodrigues JCV, Chiavegatto LG, Piza CT, Morozini W (1997) Green spot of passion fruit, a possible viral disease associated with infestation by the mite Brevipalpus phoenicis. Fitopatologia Brasileira 22:555-559. 
Kitaijma EW, Rodrigues JCV, Freitas-Astúa J (2010) An annotated list of ornamentals naturally found infected by Brevipalpus mite transmitted viruses. Scientia Agricola 67:348-371.

Kobori T, Miyagawa M, Nishioka K, Ohki ST, Osaki T (2002) Amino acid 129 of Cucumber mosaic virus coat protein determines local symptom expression and systemic movement in Tetragonia expansa, Momordica charantia and Physalis floridana. Journal General of Plant Pathology 68:81-88.

Kubo KS, Freitas-Astúa J, Machado MA, Kitajima EW (2009) Orchid fleck symptoms may be caused naturally by two different Brevipalpus transmitted viruses. Journal of General Plant Pathology 75:250-256.

Kubo KS, Novelli VM, Bastianel M, Locali-Fabris EC, AntonioliLuizon R, Machado MA, Freitas-Astúa J (2011) Detection of Brevipalpus-transmitted viruses in their mite vectors. Experimental and Applied Acarology 54:33-39.

Lan P, Yeh WB, Tsai CW, Lin NS (2010) A unique glycine-rich motif at the N-terminal region of Bamboo mosaic virus coat protein is required for symptom expression. Molecular PlantMicrobe Interactions 23:903-914.

Lee CC, Ho YN, Hu RH, Yen YT, Wang ZC, Lee YC, Hsu YH, Meng M (2011) The Interaction between Bamboo mosaic virus replication protein and coat protein is critical for virus movement in plant hosts. Journal of Virology 85:12022-12031.

Liu S, He X, Park G, Josefsson C, Perry K L (2002) A conserved capsid protein surface domain of Cucumber mosaic virus is essential for efficient aphid vector transmission. Journal of Virology 76:9756-9762.

Locali EC, Freitas-Astúa J, Souza AA, Takita MA, Astúa-Monge G, Antonioli R, Kitajima EW, Machado MA (2003) Development of molecular tool for the diagnosis of leprosis, a major threat to citrus production in the Americas. Plant Disease 87:1317-1321.

Locali-Fabris EC, Freitas-Astúa J, Souza AA, Takita MA, AstúaMonge G, Antonioli-Luizon R, Rodrigues V, Targon MLPN, Machado MA (2006) Complete nucleotide sequence, genomic organization and phylogenetic analysis of Citrus leprosis virus cytoplasmic type. Journal of General Virology 87:2721-2729.

Locali-Fabris EC, Freitas-Astúa J, Machado MA (2012) Genus Cilevirus. In: King AMQ, Adams MJ, Carstens EB, Lefkowitz EJ (Eds.) Virus Taxonomy: Ninth Report of the International Committee on Taxonomy of Viruses. San Diego CA, USA. Elsevier Academic Press. pp. 1139-1142.
Mattos Júnior D, De Negri J, Pio RM, Pompeu Júnior J (Ed.). Citros. Campinas SP. IAC.

Maunsbach AB, Afzelius BA (1999) Biomedical electron microscopy: Illustrated methods and interpretations. San Diego CA, USA. Academic Press.

Mowat WP, Dawson S (1987) Detection of plant viruses by ELISA using crude sap extracts and unfractionated antisera. Journal of Virological Methods 15:233-247.

Müller GW, Targon MLPN, Carvalho SA, Souza AA, Rodrigues JCV (2005) Doenças de citros causadas por vírus e viróides. In: Mattos Júnior D, De Negri JD, Pio RM, Pompeu Júnior J (Eds.). Citros. Campinas SP. IAC. pp. 567-604.

Pascon RC, Kitajima JP, Breton MC, Assumpção L, Greggio C, Zanca AS, OkuraVK, Alegria MC, Camargo ME, Silva GC, Cardozo JC, Vallin MA, Franco SF, Silva VH, Jordão Jr H, Oliveira-Giachetto PF, Ferrari F, Aguilar-Vildoso CI, Franchiscini FJB, Silva JMF, Arruda P, Ferro JA, Reinach F, Silva ACR (2006) The complete nucleotide sequence and genomic organization of Citrus leprosis associated virus, cytoplasmic type (CiLV-C). Virus Genes 32:289-298.

Redinbaugh MG, Hogenhout SA (2005) Plant rhabdoviruses. Current Topics in Microbiology and Immunology 292:143-63.

Rodrigues JCV, Kitajima EW, Childers CC, Chagas CM (2003) Citrus leprosis virus vectored by Brevipalpus phoenicis (Acari: Tenuipalpidae) on citrus in Brazil. Experimental and Applied Acarology 30:161-179.

Schoelz JE, Harries PA, Nelson RS (2011) Intracellular transport of plant viruses: Finding the door out of the cell. Molecular Plant $4: 813-831$

Uzest M, Gargani D, Drucker M, Hébrard E, Garzo E, Candresse T, Fereres A, Blanc S (2007) A protein key to plant virus transmission at the tip of the insect vector stylet. Proceedings of the National Academy of Sciences of the USA 146:17959-17964.

Vandenbosch KA (1990) Immunogold labeling In: Hall JL, Hawes C (Eds.) Electron microscopy of plant cells. San Diego CA, USA. Academic Press. pp. 181-218.

Vergani AR (1942) La transmisión de la lepra explosiva de la ligustrina por ácaros. Revista Argentina de Agronomia 9:292294.

Yi G, Letteney E, Kim CH, Kao CC (2009) Brome mosaic virus capsid protein regulates accumulation of viral replication proteins by binding to the replicase assembly RNA element. RNA 15:615626. 